Jurnal Ekonomi Pembangunan, 18 (2), 2017, 213-224

\title{
Regression Models for Spatial Data: an Example from Gross Domestic Regional Bruto in Central Java Province
}

\begin{tabular}{|c|}
\hline $\begin{array}{c}\text { Abdul Karim }{ }^{1}, \text { Akhmad Faturohman }^{2}, \text { Suhartono }^{3}, \text { Dedy Dwi Prastyo } \\
\text { Budi Manfaat }\end{array}$ \\
\hline $\begin{array}{l}\text { (1)Dept. of Statistics, Muhammadiyah University of Semarang, } \\
{ }^{(2)} \text { Dept. of Statistics, Muhammadiyah University of Semarang, } \\
{ }^{(3)} \text { Dept. of Statistics, Institut Teknologi Sepuluh Nopember, } \\
{ }^{(4)} \text { Dept. of Statistics, Institut Teknologi Sepuluh Nopember, } \\
\text { (5)Dept. of Mathematics, IAIN Syekh Nurjati Cirebon, } \\
\text { Corresponding Author: abdulkarim@unimus.ac.id }\end{array}$ \\
\hline
\end{tabular}

Received: July 2017| Revised: November 2017 | Accepted: November 2017

\begin{abstract}
The important role of a region's transportation infrastructure strongly affects the economic growth of the region and tends to affect the surrounding areas. The effect is called spillover effect. The aim of the research was to recognize the direct effect and spillover effect (indirect) of transportation infrastructure on the economic growth in Central Java. To identify the spillover effects, it is necessary to recognize the different characteristics of each region which have the implications on the various transportation infrastructures at each region in Central Java. Therefore, the spatial modeling was conducted. In this study, the spatial modeling employed was Spatial Durbin Error Model (SDEM). The SDEM is another form of Spatial Error Model (SEM). It does not allow for lag effects of endogenous variables, but it allows for spatial error and spatial lag on exogenous variables in which it simplifies the interpretations on direct effects and spillover effect. According to SDEM estimates, the transportation infrastructures at the districts/municipalities in Central Java had no significant effect on the outputs at each region where the infrastructures were located and their neighboring districts/cities.
\end{abstract}

Keywords: Spatial Durbin Error Model, Spatial Error Model, Spatial Econometrics, Transportation Infrastructure, Economic Growth

JEL Classification: R11, R12, F43, C21

How to cite: Karim, A., Faturohman, A., Suhartono, S., Prastyo, D., \& Manfaat, B. (2017). Regression Models for Spatial Data: An Example from Gross Domestic Regional Bruto in Province Central Java. Jurnal Ekonomi Pembangunan: Kajian Masalah Ekonomi dan Pembangunan, 18(2), 72-83. doi:https://doi.org/10.23917/jep.v18i2.4660

DOI: https://doi.org/10.23917/jep.v18i2.4660

\section{Introduction}

Central Java province is one of the provinces in Java. The economic growth of Central Java in 2014 (5.42\%), which was indicated by the growth rate of Gross Regional Domestic Product (GRDP) at the constant price of 2010, was higher than the previous year $(5.14 \%$ in 2013$)$. It is quite reasonable given the relatively stable economic conditions since the onset of the global crisis in 2014 (Statistik, B.P, 2015). Figure 1 shows the trend of the economic growth in Central Java compared with the national economic growth. The economic growth in Central Java has continued to increase since 2013. In 2012 and 
Jurnal Ekonomi Pembangunan, 18 (2), 2017, 213-224

2013, Indonesia's economic growth was at 5.34 $\%$ and $5.14 \%$ respectively, while there was an upward trend in 2014 of 5.42 percent and 5.44 percent in 2015 (Statistik, B.P, 2016). In contrast to Indonesia's economic growth that declined in the last 3 years, the economic growth of Central Java was in an upward trend and higher than the national economic growth.

A relational approach to understanding differing economic geographies indicates that network systems are a key component of the regional development mix (Huggins \& Thompson, 2017). The increase in the connectivity of districts and municipalities in Central Java has the impact on the productivity capability of each region to grow its economy. The increased rate of economic growth described earlier in this paper indicates that there is an increase in production capacity and economic process in Central Java. The increase in the number of products, goods and services also means that there is an increase in the number of the production factors used.

The existence of the different characteristic or phenomena structures owned by districts and cities such as the differences in capital value, number of labor, human capital, and transportation infrastructure can cause the variation of economic growth in each region. Moreover, it does not mean that each region is independent or unaffected by one another. All these consequences do not only occur in the areas where transport infrastructures are located, but they may also spread to neighboring areas. Increased inter-regional connectivity and/ or geographic proximity as well as characteristic similarity are the indicators of spillover effect.

The development of transportation infrastructure should be able to encourage economic growth in Central Java. In line with the increase in population demography, it is expected to encourage an increase in the use of transportation infrastructures. Animportantissue in this context is the influence of transportation infrastructure in meeting the growing demand of the people, so that it is required to meet the transportation needs in Central Java Province. Good regional connectivity is the goal in meeting the demand in the community so as to reduce capital, time and energy, because transportation is the main sector and the driver for economic growth in Central Java. The differences of regional characteristics have the implications on varied regional transportation infrastructure. Therefore, to see the effect of regional data-based

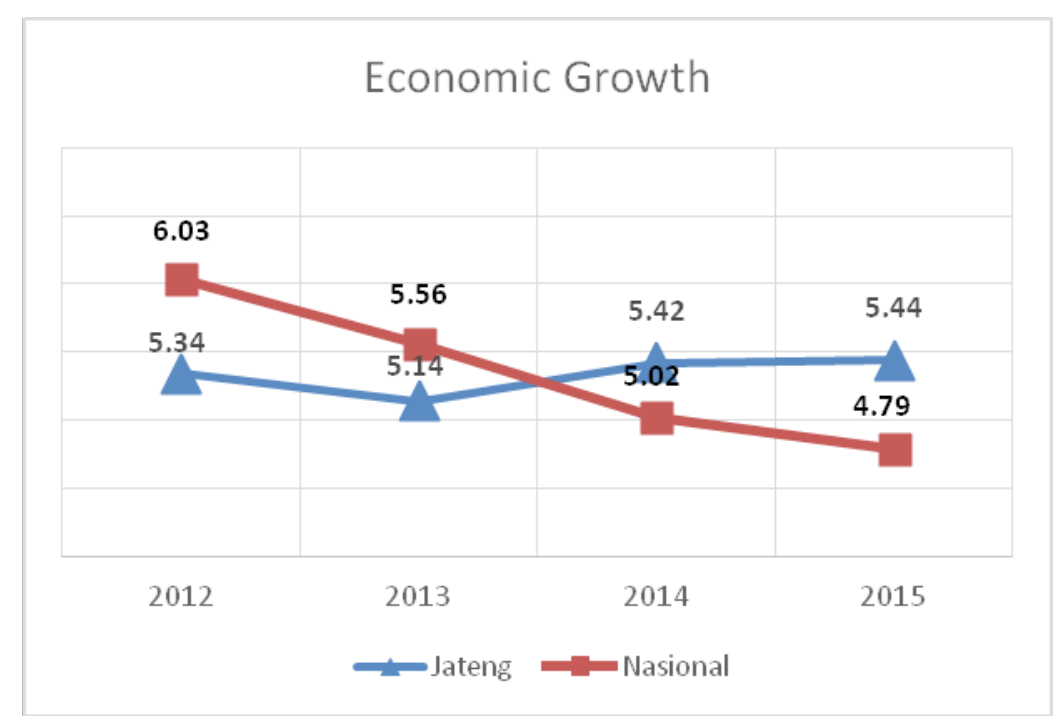

Figure1. The Comparison of the Economic Growth in Central Java and National 
transportation infrastructure with the approach of spatial durbin error model is a smart solution in solving the problems of the above phenomenon.

The first law on geography was proposed by Tobler (Ho \& Hensher, 2016), which is the condition at one point or an area in relation with the condition of one of the points or adjacent areas. This law is the foundation for regional scientific studies, and the observations at one location frequently depend on the observations in other locations. To overcome this, the regression model is developed using spatial econometrics approach. Spatial effects often occur between one and another region.in spatial data, the observations at a location frequently depend on the observations in other neighboring locations.

The model of spatial econometrics has become increasingly popular in the applied econometrics of the last two decades, and the challenge and evolution in thinking of the best way to incorporate spatial heterogeneity in econometric models have emerged with this popularity (Lacombe \& McIntyre, 2016). In spatial econometrics modeling, there are spatial autoregressive model (SAR) and spatial error model (SEM) as the special case of autoregressive spatial indicated by the addition of the effect of endogenous and exogenous lag variable known as spatial durbin model (SDM). In SDM, it has spatial lag in exogenous and endogenous variables, where $\beta_{2}$ is the lag spatial parameter in $W_{1} X$. One alternative to SEM model is spatial durbin error model (SDEM), which does not allow for the effect of endogenous lag variable, but it allows for spatial error and spatial lag in exogenous variables. SDEM simplifies the interpretation of the direct impacts represented by the parameter model $B$ and the indirect impact on Y. SDEM replaces the global multiplier found in SDM, with local multiplier that makes it easier to interpret from model estimates (Lesage, 2008) (Karim, A \& Wasono, R, 2017).

A review on the impact of transport infrastructure on economic growth had been undertaken by Banerjee, Duflo, \& Qian (2012) which examined the relationship of the transport infrastructure access and economic growth in China by considering variables of inter-city distance using regression analysis through the Cobb-Douglas methodology. Furthermore, Arbués, Baños, \& Mayor (2015) used spatial durbin model (SDM) found road transport infrastructure positively affects the output of the region in which the infrastructure is located and its neighboring provinces, while the remaining modes of transportation projects cause no significant impacts on average. Li, Wen, \& Jiang (2017) also focused on the impacts of the transport infrastructure on regional economic growth in Chinese New Silk Road Economic Belt using SDM, obtaining the transport infrastructure plays an obvious lead role in regional economy growth alongside the NSREB, and the economic growth invigorates common development in surrounding regions. In addition, differences were observed among the different transport infrastructure with regard to their influences on regional economic development, as the highway transport affects regional economic growth to a larger degree than railway transport.

The primary goal of this paper is to estimate the contribution of transportation infrastructure to the regional economy by incorporating spatial effects and utilizing spatial econometrics techniques. The resulting model is applied to Province Central Java, where transportation infrastructure have been promoted through the implementation of the Infrastructure and Transport Strategic Plan that raised the quality of Province Central Java transportation network to National standards in a short period of time.

\section{Literature Review \\ 2.1 Regression Analysis}

Regression analysis is one of the statistical methods that study the pattern of relationship mathematically between one dependent variable and one or more independent variables. The goal is to find out the value of dependent variable on the basis of the effect of independent variables. 
Jurnal Ekonomi Pembangunan, 18 (2), 2017, 213-224

Mathematically, (Faraway, 2016) wrote as follows:

$$
\mathbf{Y}_{t}=\beta_{0}+\beta_{1} \mathbf{X}_{1 t}+\varepsilon_{t}
$$

where:

$\begin{aligned} t & =1,2, \ldots, \mathrm{R} \\ \mathrm{y}_{\mathrm{t}} & \text { dependent variable } \\ \mathbf{X}_{1 \mathrm{t}}, \mathbf{X}_{2 \mathrm{t}}, \ldots, \mathbf{X}_{\mathrm{kt}}= & \text { independent variable with } \\ & \text { the nature of permanent } \\ = & \text { number of independent } \\ k & \text { variables } \\ = & \text { regression parameters } \\ = & \text { error (difference between } \\ \beta_{0}, \beta_{1}, \quad & \text { dependent variable and } \\ \varepsilon_{t} & \text { regression model assessment) }\end{aligned}$

If the linear regression model in (1) is expressed in the form of the equation $\mathrm{Y}=\mathrm{XB}+\varepsilon$ where $\mathrm{Y}$ and $\varepsilon$ are the vectors with the dimension $\mathrm{R} \times 1$, and $\mathrm{X}$ is a matrix with theh size $\mathrm{R} \times(\mathrm{k}+1)$, and $B$ is a vector with the dimension $(k+1) \times 1$, then using OLS estimates (Casela, Feinberg and Olkin, 2009):

$$
\hat{\beta}=\left(\mathbf{X}^{T} \mathbf{X}\right)^{-1} \mathbf{X}^{T} \mathbf{y}
$$

\subsection{Spatial Econometrics}

Econometrics is a science that applies economics theory, economics mathematics, and economics statistics to provide empirical support from the models built by economics theory and to produce the results in figures. Economics theory plays a role to make hypotheses which are generally qualitative on the relationship between economics variables and modeled economics phenomena. Economics mathematics plays the role to formulate economics theory in the form of mathematical equations with no regard to theory empirically, while statistics plays the roles in collecting empirical data, changing a model into Econometrics model, data processing, selecting and applying precise estimates to regression parameters and testing hypotheses and model accuracy. An econometric model is considered good when it is able to analyze structurally and to predict and evaluate policy (Setiawan and Kusrini, 2010).

The development of econometrics is econometrics spatial. From the development, the economic phenomenon occurred is presumed to have a relationship when viewed from the aspect of location and others. Beginning with Tobler's first law (Ho \& Hensher, 2016), the conditions at one point or area correspond to the conditions at one point or the adjacent area.

Anselin described two spatial effects in econometrics including the effects of spatial dependence and spatial heterogeneity (Ciccarelli \& Fachin, 2016). Spatial dependence indicates an autocorrelation among research object locations (cross sectional data set). Spatial heterogeneity refers to the diversity of functional forms and parameters at each location, the study sites did not indicate homogeneity in the data. In general, spatial model can be stated in the equation (3).

$$
\begin{aligned}
& \mathbf{y}=\rho \mathbf{W} \mathbf{y}+\mathbf{X} \boldsymbol{\beta}+\mathbf{u} \\
& \mathbf{u}=\lambda \mathbf{W u}+\varepsilon \\
& \varepsilon \sim N\left(0, \sigma^{2} \mathbf{I}\right)
\end{aligned}
$$

where $\mathbf{y}$ is $(N \times 1)$ vector of the dependent variable, $\mathbf{X}$ is $(N \times \mathrm{p})$ matrix of the independent variable, $\boldsymbol{\beta}$ is $(p \times 1)$ vector in the regression coefficient, $\mathbf{W}$ is the $(N \times N)$ weight matrix which states the relationship between $N, \rho$ and $\lambda$, which is the dependency spatial parameter, and $\boldsymbol{\varepsilon}$ is an independent and identical distributed vector (i.i.d).

\subsection{Weight Matrix}

Spatial Weight Matrix (W) can be obtained from inter-regional contiguity and neighborhood distance or the distance between all regions. Spatial weights specifications vary according to conceptualizations; popular ones include: contiguity, continuous distance, nearest neighbor distances, fixed distance band, and spatial interaction. (Griffith, Griffith, \& A., 2017) 


\subsection{Spatial Durbin Error Model}

Lesage and Pace (2008) introduced the SEM (spatial error model) with the equation:

$$
\begin{aligned}
& \mathrm{y}=\mathrm{X} \beta+\mathrm{u} \\
& \mathrm{u}=\lambda \mathrm{Wu}+\varepsilon
\end{aligned}
$$

The equations of (4) and (5) can be completed and it can be obtained the value of $u$ :

$\mathrm{u}=\lambda \mathrm{Wu}+\varepsilon$

$\mathrm{u}-\lambda \mathrm{Wu}=\varepsilon$

$(\mathrm{I}-\lambda \mathrm{W}) \mathrm{u}=\varepsilon$

$\mathrm{u}=(\mathrm{I}-\lambda \mathrm{W})^{-1} \varepsilon$

From the equations of (4) and (6),

$\mathrm{y}=\mathrm{X} \beta+(\mathrm{I}-\lambda \mathrm{W})^{-1} \varepsilon$

Then, Lesage and Pace (2008) introduced spatial durbin error model (SDEM), with the addition of spatial lag in the independent variable

$y_{\mathrm{i}}=\beta_{0}+\sum_{\mathrm{k}=1}^{l} \beta_{1 \mathrm{k}} x_{\mathrm{ki}}+\sum_{\mathrm{k}=1}^{l} \beta_{2 \mathrm{k}} \sum_{\mathrm{j}=1}^{\mathrm{n}} w_{\mathrm{ij}} x_{\mathrm{kj}}+(I-\lambda \mathbf{W})^{-1} \varepsilon$

It can be rewritten in matrix notation as follows:

$\mathrm{y}=\mathrm{Z} \beta+(\mathrm{I}-\lambda \mathrm{W})^{-1} \varepsilon$

where $\mathbf{Z}=[\mathbf{I} \mathbf{X} \mathbf{W X}]$ and $\hat{\mathbf{a}}=\left[\begin{array}{lllll}\beta_{0} & \beta_{1} & \beta_{2} & \beta_{3} & \beta_{4}\end{array}\right]^{T}$

, WX are the spatial lag in $\mathbf{X}$, and $\boldsymbol{I}$ is the identity matrix.

\subsection{Estimation of the Parameter of Spatial Durbin Error Model (SDEM)}

The method of Maximum Likelihood Estimation (MLE) was used to estimate the parameter of SDEM. From the equation (8), the likelihood function was formed, and the formation of the likelihood function is made through error $\varepsilon$. The result of the function formation is in the equation (9)

$$
\begin{aligned}
& \mathrm{y}=\mathrm{Z} \beta+(\mathrm{I}-\lambda \mathrm{W})^{-1} \varepsilon \\
& \varepsilon=\mathrm{y}(\mathrm{I}-\lambda \mathrm{W})-(\mathrm{I}-\lambda \mathrm{W}) \mathrm{Z} \beta \\
& \varepsilon=(\mathrm{I}-\lambda \mathrm{W})(\mathrm{y}-\mathrm{Z} \beta)
\end{aligned}
$$

where, $\quad \mathbf{Z}=\left[\begin{array}{llll}I X_{1} & X_{2} & W X_{1} & W X_{2}\end{array}\right] \quad$ and $\beta=\left[\mathrm{I} \beta_{0} \beta_{1} \beta_{2} \beta_{3} \beta_{4} \beta_{5}\right]$ $J=\left|\frac{\partial u}{\partial y}\right|=|I-\lambda \mathbf{W}|$

Then the result is;

$\mathrm{L}\left(\lambda, \beta, \sigma^{2} ; \mathrm{y}\right)=(2 \pi)^{-\frac{\mathrm{n}}{2}}\left(\sigma^{2}\right)^{-\frac{\mathrm{n}}{2}}|\mathrm{~J}| \mathrm{e}^{\left\{-\frac{1}{2 \sigma^{2}} \varepsilon^{\mathrm{T}} \varepsilon\right\}}$

$$
\begin{aligned}
& \mathrm{L}\left(\lambda, \beta, \sigma^{2} ; \mathrm{y}\right)= \\
& (2 \pi)^{-\frac{\mathrm{n}}{2}}\left(\sigma^{2}\right)^{-\frac{\mathrm{n}}{2}}|\mathrm{I}-\lambda \mathrm{W}| \mathrm{e}^{\left\{-\frac{1}{2 \sigma^{2}}[(\mathrm{I}-\lambda W)(\mathrm{y}-\mathrm{Z} \beta)]^{\mathrm{T}}[(\mathrm{I}-\lambda W)(\mathrm{y}-\mathrm{Z} \beta)]\right\}}
\end{aligned}
$$

Natural Logarithm Operation (ln likelihood) in the equation of (16)

$$
\begin{aligned}
& \ln \mathrm{L}\left(\lambda, \beta, \sigma^{2} ; \mathrm{y}\right)=\mathrm{c}-\frac{\mathrm{n}}{2}\left(\sigma^{2}\right)+\ln |\mathrm{I}-\lambda \mathrm{W}|-\frac{1}{2 \sigma^{2}} \\
& {[(\mathrm{I}-\lambda \mathrm{W})(\mathrm{y}-\mathrm{Z} \beta)]^{\mathrm{T}}[(\mathrm{I}-\lambda \mathrm{W})(\mathrm{y}-\mathrm{Z} \beta)]^{2}}
\end{aligned}
$$

From the equation of (10), the estimators of parameters $\hat{\beta}, \hat{\lambda}$ and $\hat{\sigma}^{2}$ are obtained.

\subsection{Estimation of Parameter $\hat{\beta}$}

The estimator parameter $\hat{\beta}$ was obtained by maximizing the function of ln likelihood of the equation (10), which is the first derivative of the equation to and makes it equal to zero, as follows: 
$\frac{\partial \mathrm{L} \pi\left(\lambda, \beta, \sigma^{2} ; \mathrm{y}\right)}{\partial \beta}=0$

$\frac{\partial\left\{\mathrm{c}-\frac{\mathrm{n}}{2} \ln \left(\sigma^{2}\right)+\ln |\mathrm{I}-\lambda \mathrm{W}|-\frac{1}{2 \sigma^{2}}[(\mathrm{I}-\lambda \mathrm{W})(\mathrm{y}-\mathrm{Z} \beta)]^{\mathrm{T}}[(\mathrm{I}-\lambda \mathrm{W})(\mathrm{y}-\mathrm{Z} \beta)]\right\}}{\partial \beta}=0$

$\frac{1}{\sigma^{2}}\left\{\left[\mathrm{Z}^{\mathrm{T}}(\mathrm{I}-\lambda \mathrm{W})^{\mathrm{T}}(\mathrm{I}-\lambda \mathrm{W}) \mathrm{y}\right]-\left[\mathrm{Z}^{\mathrm{T}}(\mathrm{I}-\lambda \mathrm{W})^{\mathrm{T}}(\mathrm{I}-\lambda \mathrm{W}) \mathrm{Z}\right] \beta\right\}=0$

$\beta^{\mathrm{E}}=\left[\mathrm{Z}^{\mathrm{T}}(\mathrm{I}-\lambda \mathrm{W})^{\mathrm{T}}(\mathrm{I}-\lambda \mathrm{W}) \mathrm{Z}\right]^{-1}\left[\mathrm{Z}^{\mathrm{T}}(\mathrm{I}-\lambda \mathrm{W})^{\mathrm{T}}(\mathrm{I}-\lambda \mathrm{W}) \mathrm{y}\right]$

\subsection{Estimation of Parameter $\hat{\sigma}^{2}$}

The estimation of parameter $\hat{\sigma}^{2}$ was obtained by the first derivative of the equation
(10) to $\hat{\sigma}^{2}$ and making it equal to zero, as follows:

$$
\begin{aligned}
& \frac{\partial \mathrm{L} \pi\left(\lambda, \beta, \sigma^{2} ; \mathrm{y}\right)}{\partial \sigma^{2}}=0 \\
& \frac{\partial\left\{\mathrm{c}-\frac{\mathrm{n}}{2} \ln \left(\sigma^{2}\right)+\ln |\mathrm{I}-\lambda \mathrm{W}|-\frac{1}{2 \sigma^{2}}[(\mathrm{I}-\lambda \mathrm{W})(\mathrm{y}-\mathrm{Z} \beta)]^{\mathrm{T}}[(\mathrm{I}-\lambda \mathrm{W})(\mathrm{y}-\mathrm{Z} \beta)]\right\}}{\partial \sigma^{2}}=0 \\
& -\frac{\mathrm{n}}{2 \sigma^{2}}+\frac{1}{2 \sigma^{2}}[(\mathrm{I}-\lambda \mathrm{W})(\mathrm{y}-\mathrm{Z} \beta)]^{\mathrm{T}}[(\mathrm{I}-\lambda \mathrm{W})(\mathrm{y}-\mathrm{Z} \beta)]=0 \\
& \partial \mathrm{E}=\frac{1}{\mathrm{n}}[(\mathrm{I}-\lambda \mathrm{W})(\mathrm{y}-\mathrm{Z} \beta)]^{\mathrm{T}}[(\mathrm{I}-\lambda \mathrm{W})(\mathrm{y}-\mathrm{Z} \beta)]
\end{aligned}
$$

\subsection{Estimation of Parameter $\hat{\lambda}$}

The estimator $\hat{\lambda}$ cannot be obtained from the residual of OLS, and the estimator $\hat{\lambda}$ is obtained from the explicit form of the concentrated $\mathrm{ln}$ likelihood function (Anselin, 2001). Substituting the equations (11) and (12) into the equation (10) and ignoring the constants, then:

$\ln L(\lambda)=-\frac{\mathrm{n}}{2} \ln \left\{\frac{1}{\mathrm{n}}(\mathrm{y}-\mathrm{Z} \beta)^{\mathrm{T}}(\mathrm{y}-\mathrm{Z} \beta)\right\}+\ln |\mathrm{I}-\lambda \mathrm{W}|$

Because it is not closed form, the completion to find the parameter estimation was conducted using iterative method.

\subsection{Transport Infrastructure Regional Economic Growth}

and

In general, when viewed from the quality of infrastructure in Indonesia in the Report of the World Economic Forum 2017, Indonesia was in $41^{\text {th }}$ rank out of 138 countries. Similarly, in 2016, although Indonesia's infrastructure development showed its progress in the $41^{\text {st }}$ rank, it is still far left behind Singapore which ranked in the $2^{\text {nd }}$, Malaysian in $25^{\text {th }}$ rank, and Thailand in $34^{\text {th }}$ rank as outlined in Figure 1.

The Government through the Presidential Regulation No. 75 of 2014 on the Committee for the Acceleration of Infrastructure Provision describes several types of infrastructure provisions 
regulated by the government, i.e.: transport infrastructure, road infrastructure, irrigation infrastructure, drinking water and sanitation infrastructures, telematics infrastructure, electricity infrastructure, and oil transport and natural gas infrastructures. The classification of the above infrastructures can be categorized as basic infrastructures because they are needed by broader community and it has to be regulated by the government.

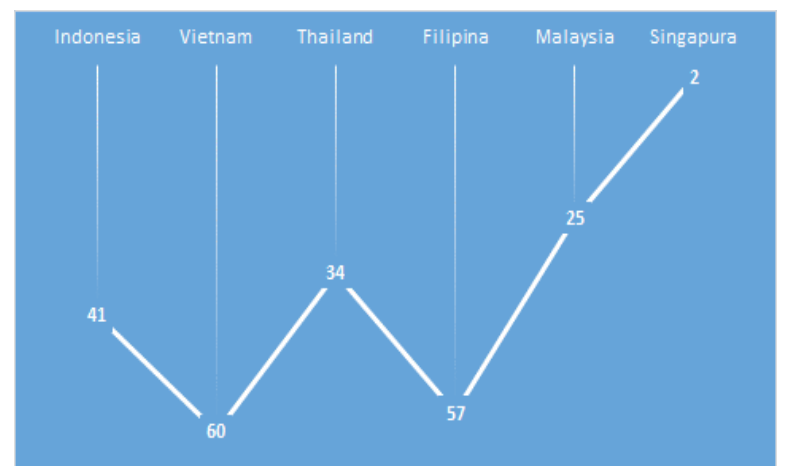

Figure 2 Achievement of Global

Competitiveness Pillar in 2016

Source: Competitiveness Global Report 2016-2017
Transport infrastructure plays a role in creating the value of a good. Based on neoclassical theory, an item has the value according to the production cost or specifically by labor sacrifice cost issued thereon. Transportation is a tool that can create higher value in goods so that the goods can meet consumer needs ( $\mathrm{Li}$ et al., 2017). In this case, transportation provides the value for goods through the process of moving the goods from the center of production to the center of consumption. The creation of the value for goods by transportation makes transportation a valuable tool economically.

Thus, the development of transportation infrastructure is one important aspect in accelerating the process of national development as well as driving sectoral economic growth.

\section{METHOD}

\subsection{Data}

The data used in this research were the data obtained from the Statistic Indonesia (BPS) of the Districts and Cities in Central Java Province in 2015.

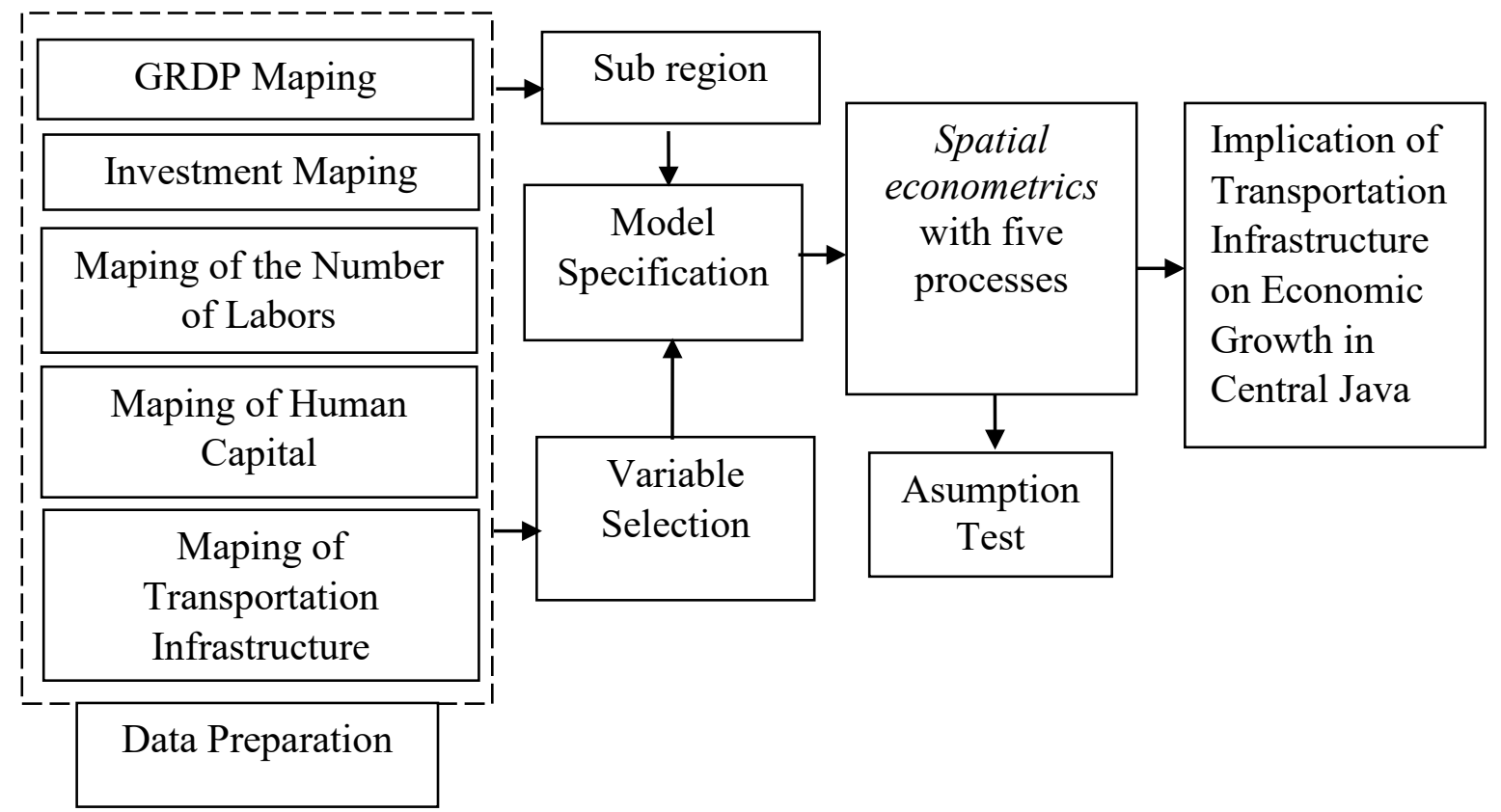

Figure 3 Research Framework 
Avalaible online at http://journals.ums.ac.id, Permalink/DOI: 10.23917/jep.v18i2.4660

Jurnal Ekonomi Pembangunan, 18 (2), 2017, 213-224

Table 1 Definition of Operational Variables

\begin{tabular}{|c|c|c|c|c|}
\hline No & Variable & Indicator & $\begin{array}{l}\text { Analysis } \\
\text { Unit }\end{array}$ & $\begin{array}{c}\text { Data } \\
\text { Sources }\end{array}$ \\
\hline \multicolumn{5}{|c|}{ Endogenous (Y) } \\
\hline 1 & GRDP (Y) & Gross Regional Domestic Product (GRDP) & $\begin{array}{l}\text { Million } \\
\text { Rupiah }\end{array}$ & $\begin{array}{l}\text { BPS } \\
\text { District/ } \\
\text { City }\end{array}$ \\
\hline \multicolumn{5}{|c|}{ Exogenous (X) } \\
\hline 2 & $\begin{array}{l}\text { Number of Labors } \\
\text { (X2) }\end{array}$ & $\begin{array}{l}\text { Labor value for each district and city in Central } \\
\text { Java }\end{array}$ & person & $\begin{array}{l}\text { BPS } \\
\text { District/ } \\
\text { City }\end{array}$ \\
\hline 3 & Human capital (X3) & $\begin{array}{l}\text { Human capital approached with the number of } \\
\text { residents with the lowest education of Junior High } \\
\text { School for each district and city in Central Java }\end{array}$ & person & $\begin{array}{l}\text { BPS } \\
\text { District/ } \\
\text { City }\end{array}$ \\
\hline 4 & $\begin{array}{l}\text { Transportation } \\
\text { Infrastructure (X4) }\end{array}$ & $\begin{array}{l}\text { Length of roads with the conditions of good and } \\
\text { medium }(\mathrm{km}) \text { for each district and city in Central } \\
\text { Java }\end{array}$ & $\mathrm{Km}$ & $\begin{array}{l}\text { BPS } \\
\text { District/ } \\
\text { City }\end{array}$ \\
\hline
\end{tabular}

\subsection{Research Variable and Spesifications Models}

This study used the variables used by (Arbués et al., 2015) who used SDM with the Cobb-Douglas methodology. The difference was in the development of the spatial durbin error model. Table 1 shows the definitions of the variables used.

The designs of spatial econometrics model with two proposed spatial processes are:

a. SEM Model

$y=\beta_{0}+X_{1} \beta_{1}+X_{2} \beta_{2}+X_{3} \beta_{3}+X_{4} \beta_{4}+(I-\lambda W)^{-1} u$

b. SDEM model:

$y=\beta_{0}+X_{1} \beta_{1}+W_{1} X_{1} \beta_{1}+X_{2} \beta_{2}+W_{2} X_{2} \beta_{2}+X_{3} \beta_{3}+W_{3} X_{3} \beta_{3}+X_{4} \beta_{4}+W_{4} X_{4} \beta_{4}+(I-\lambda W)^{-1} u$

\subsection{Analysis Method}

To model the response variables, the data structure processed can be seen in Table 2 .

Table 2. Data Structure of Rice Production

\begin{tabular}{ccccc}
\multicolumn{5}{c}{ Modelling } \\
\hline District/City & $\mathrm{Y}$ & $\mathrm{X}_{1}$ & $\mathrm{X}_{2}$ & $\mathrm{X}_{3}$ \\
\hline 1 & $\mathrm{y}_{1}$ & $\mathrm{x}_{11}$ & $\mathrm{x}_{21}$ & $\mathrm{x}_{31}$ \\
2 & $\mathrm{y}_{2}$ & $\mathrm{x}_{12}$ & $\mathrm{x}_{22}$ & $\mathrm{x}_{32}$ \\
$\vdots$ & $\vdots$ & $\vdots$ & $\vdots$ & $\vdots$ \\
35 & $\mathrm{y}_{35}$ & $\mathrm{x}_{135}$ & $\mathrm{x}_{235}$ & $\mathrm{x}_{335}$ \\
\hline
\end{tabular}

The followings are the stages of the analysis for each method in accordance with the formulation of research problems,

a. Mapping the GRDP value of each District and City in Central Java as the initial study to determine the spatial weight matrix.

b. Modelling the spatial error model (SEM), and spatial durbin error model (SDEM) using the method of maximum likelihood

c. Evaluating the spatial econometrics model formed by testing the error assumption so that the system of assumption regression 
Avalaible online at http://journals.ums.ac.id, Permalink/DOI: 10.23917/jep.v18i2.4660

Jurnal Ekonomi Pembangunan, 18 (2), 2017, 213-224

Table 3 Results of Parameter Estimation Test of OLS, SEM and SDEM Models

\begin{tabular}{|c|c|c|c|}
\hline Parameter & $\begin{array}{c}\text { OLS } \\
\text { Coefficient } \\
\text { (P-value })\end{array}$ & $\begin{array}{c}\text { SEM } \\
\text { Coefficient } \\
\text { (P-value })\end{array}$ & $\begin{array}{c}\text { SDEM } \\
\text { Coefficient } \\
\text { (P-value) }\end{array}$ \\
\hline \multirow[t]{2}{*}{ Intercept } & $8.005 \mathrm{e}-05$ & -0.011 & 0.44 \\
\hline & $(0.999)$ & $(0.916)$ & $\left(0.025^{*}\right)$ \\
\hline \multirow[t]{2}{*}{ Labor } & $1.814 \mathrm{e}-01$ & 0.227 & -0.007 \\
\hline & $(0.446)$ & $(0.294)$ & $\left(2,2 \mathrm{e}-16^{*}\right)$ \\
\hline \multirow[t]{2}{*}{ Human Capital } & $6.762 \mathrm{e}-01$ & 0.646 & -0.14 \\
\hline & $\left(0.003^{*}\right)$ & $\left(0.001^{*}\right)$ & $\left(2,2 \mathrm{e}-16^{*}\right)$ \\
\hline \multirow[t]{2}{*}{ Road Infrastructure } & $2.611 \mathrm{e}-01$ & -0.283 & -0.040 \\
\hline & $\left(0.137^{*}\right)$ & $\left(0.077^{* *}\right)$ & $\left(0.068^{* *}\right)$ \\
\hline \multirow[t]{2}{*}{ W*Labor } & & & 0.244 \\
\hline & & & $\left(0.014^{*}\right)$ \\
\hline \multirow[t]{2}{*}{ W*Human Capital } & & & -0.218 \\
\hline & & & $\left(0.015^{*}\right)$ \\
\hline \multirow[t]{2}{*}{$\mathrm{W} *$ Road Infrastructure } & & & -0.116 \\
\hline & & & $(0.227)$ \\
\hline \multirow[t]{2}{*}{ Lambda } & - & -0.019 & -0.125 \\
\hline & - & $(0.81)$ & $(0.09 * *)$ \\
\hline AIC & 84.326 & 86.268 & 79.669 \\
\hline
\end{tabular}

Note: *Significant at $\alpha=5 \%, * *$ Significant ata $=10 \%$

equation was obtained. The error assumptions in the spatial model included normal distributed errors, the error with a constant variance and free error.

\section{Result and Discussion}

4.1 Modelling of Rice Production in the Districts/ Cities in Central Java using Spatial Econometrics Approach

The estimations of OLS, SEM and SDEM models resulted in the parameters influencing economic growth in Central Java province with a significance level of $5 \%$. The result of the parameter estimation is presented in Table 3 as follows:

Based on the analysis on OLS, SEM and SDEM models, it can be concluded that the SDEM model is better to use because it has the smallest AIC value. SDEM is different from OLS and SEM models, because in SDEM there is a direct effect (global multiplier) and an indirect effect (multiplier). The indirect effects of SDEM are apparent from the parameters weighted by matrix W. All variables which are not weighted by matrix $\mathrm{W}$ (global multiplier) in SDEM have significant effect on GRDP. In other hand, the variables weighted by matrix $\mathrm{W}$ (local multiplier), the variables of labor and Human Capital have the significant effects on GRDP.

The lambda coefficient in SDEM is negative and significant at alpha 10 percent. It indicates that the GRDP in the adjacent districts and cities in Central Java are linked to each other, but in contrary. It means; if an area has a high economic growth, the areas nearby do not feel the significant impact of the economic growth. These coeffiients are similar to those obtained in some of the most recent applied studies in Spain (Marquez, Ramajo, \& Hewings, 2010). While the results of direct effect from Transportation Infrastructure and Labor does not match the model specification of negative marks similar to estimates by Cantos, Gumbau, Albert, \& Maudos (2005). However, 
Jurnal Ekonomi Pembangunan, 18 (2), 2017, 213-224

these two variables have no significant effect on GRDP Central Java province. This result can be interpreted that GRDP Central Java province is influenced by Human Capital globally.

Figure 4 shows the GRDP distribution of the districts and cities in Central Java in 2015. From the figure, it shows that there are regional groupings with high, medium and low GRDP values. The cities of Semarang, Cilacap and Kudus are included as the regions with high
GRDP value, while the cities of Tegal, Magelang and Pekalongan are classified as the regions with low GRDP value. Figure 4 can show that the lambda value of GRDP is negative, which shows some regions with high GRDP value but the surrounding regions have low GRDP, such as Semarang and Demak, Demak and Kudus, Brebes and Tegal, Banyumas and Purbalingga, Semarang and Grobogan, and other areas showing a negative relationship.

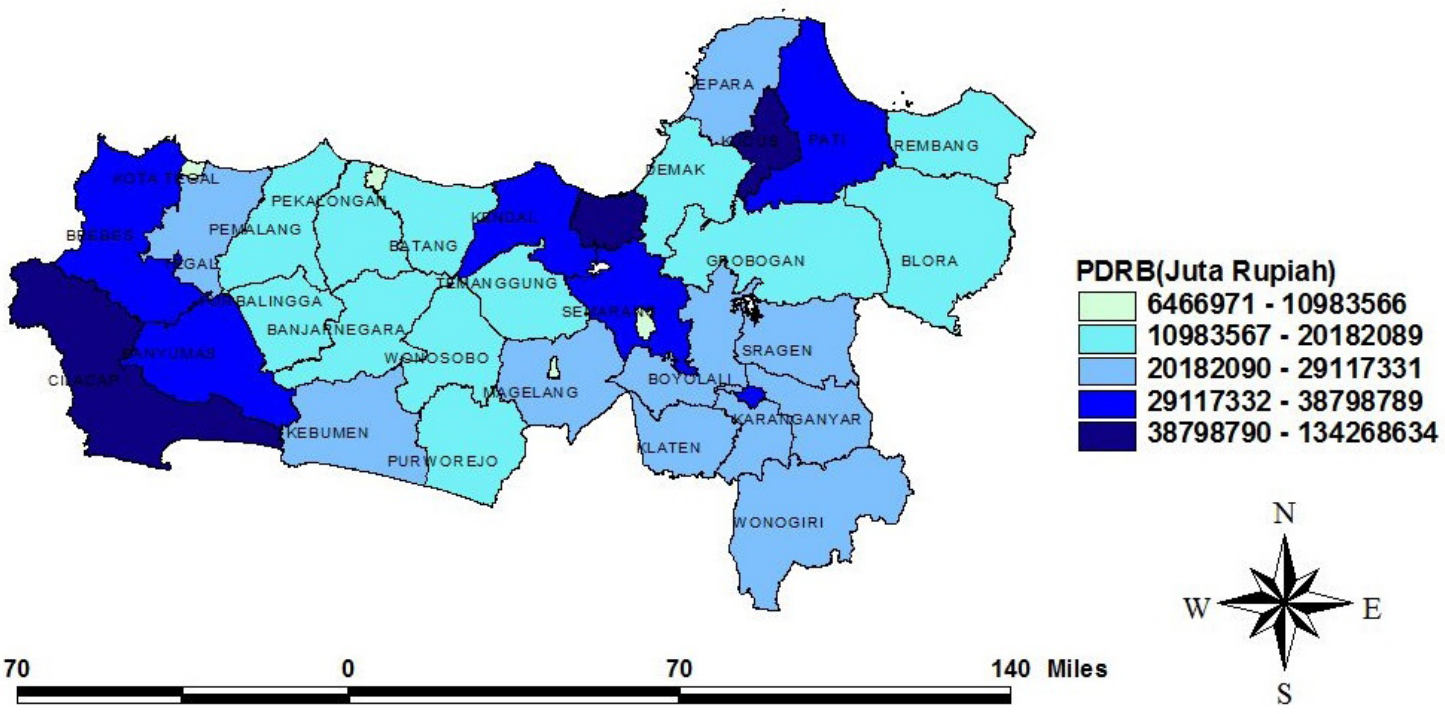

Source: Jawa Tengah dalam angka 2016 (Central Java in Figures (processed)

Figure4. The Distribution of GRDP of the Districts and Cities in Central Java *

\subsection{Diagnostic of Models Assumption}

Table 4 Evaluation of Model Assumption

\begin{tabular}{ccc}
\hline $\begin{array}{c}\text { Classic Assumption } \\
\text { Test }\end{array}$ & Criteria & SDEM \\
\hline Normality & p-value $>a$ & $M$ \\
Autocorrelation & p-value $>a$ & $M^{*}$ \\
Heteroscesdacity & $p$-value $>a$ & $M$ \\
Multicollinearity & VIF $<10$ & $M$ \\
\hline Note: $M=$ Meeting the econometrics criteria, \\
TM = Not meeting the econometrics criteria, \\
*the autocorrelation test used global moran's test
\end{tabular}


Jurnal Ekonomi Pembangunan, 18 (2), 2017, 213-224

Table 4 is an evaluation of classic assumption results. The Kolmogorov-Smirnov test of SDEM result p-value of 0.1475 that indicates the data is normally distributed. Moran's results show p-value of 0.5059 which means that no autocorrelation occurs. Then, the Breusch-Pagan test obtained $p$-value of 0.066 and the VIF value for each variable has the value lower than 10 . It means that SDEM has met the criteria of regression classic assumption.

\section{Conclusion}

The result of study have proposed an alternative modeling for economic growth in Central Java using spatial econometrics approach, we have performed several estimation procedures spatial modeling. First, we have estimated the model using ordinary least square (OLS) without spatial effect. Secondly, we have estimated two models spatial econometrics using spatial error model (SEM) and spatial durbin error model (SDEM). The results of our estimation show SDEM is the best model to model the economic growth of Central Java. SDEM shows that all variables that are not weighted by $\mathrm{W}$ have significant direct effect on the economic growth of Central Java, while the variables weighted by matrix W, Labor and Human Capital, and have the significant indirect effect on the economic growth of Central Java.

The empirical results have shown the presence of spatial effect in particular appears to support that distribution of economic growth in Central Java Province has a grouping pattern between the adjacent regions to each other. The role played by spatial effects has constituted the main focus of this analysis, the spatial effects are captured by indirect effects (spillovers).

\section{Acknowledgments}

The authors would like to express heartfelt thanks to Statistics Indonesia (BPS) Central Java. We also appreciate the Ministry of Research, Technology, and Higher Education of the Republic of Indonesia for providing financial support.

\section{References}

Anselin, L. (2001), Spatial econometrics. In: Baltagi, BH (ed) A companion totheoretical econometrics, Blackwell, Malden, MA.

Arbués, P., Baños, J. F., \& Mayor, M. (2015). The spatial productivity of transportation infrastructure. Transportation Research Part A: Policy and Practice, 75, 166-177. http://doi.org/10.1016/j.tra.2015.03.010

Banerjee, A., Duflo, E., \& Qian, N. (2012). On the Road: Access to Transportation Infrastructure and Economic Growth in China. Cambridge, MA. Retrieved from http://www.nber.org/papers/w17897.pdf

Cantos, P., Gumbau $\square$ Albert, M., \& Maudos, J. (2005). Transport infrastructures, spillover effects and regional growth: evidence of the Spanish case. Transport Reviews, 25(1), 25-50. http://doi. org/10.1080/014416410001676852

Casela, Fenberg dan Olkin. (2009). A Modern Approach to Regression with R. Springer. New York, USA.

Ciccarelli, C., \& Fachin, S. (2016). Regional growth with spatial dependence: A case study on early Italian industrialization. Papers in Regional Science. http://doi.org/10.1111/ pirs. 12217

Faraway, J. J. (n.d.). Extending the linear model with $R$ : generalized linear, mixed effects and nonparametric regression models.

Griffith, D. A., Griffith, \& A., D. (2017). Spatial Weights. In International Encyclopedia of Geography: People, the Earth, Environment and Technology (pp. 1-7). Oxford, UK: John Wiley \& Sons, Ltd. http://doi. org/10.1002/9781118786352.wbieg0200

Ho, C. Q., \& Hensher, D. A. (2016). A workplace choice model accounting for spatial competition and agglomeration effects. Journal of Transport Geography, 51, 193-203. http://doi.org/10.1016/j. jtrangeo.2016.01.005

Huggins, R., \& Thompson, P. (2017). Networks and regional economic growth: A spatial 
Jurnal Ekonomi Pembangunan, 18 (2), 2017, 213-224

analysis of knowledge ties. Environment and Planning A, 49(6), 1247-1265. http:// doi.org/10.1177/0308518X17692327

Karim, A., \& Wasono, R. (2017). Modeling of Rice Production in Central Java Using Spatial Panel. Advanced Science Letters, 23(7), 6530-6532.

Lacombe, D. J., \& McIntyre, S. G. (2016). Local and global spatial effects in hierarchical models. Applied Economics Letters, 23(16), 1168-1172. http://doi.org/10.1080/1350485 1.2016.1142645

LeSage J \& Pace RK, (2008), Introduction to spatial econometrics, CRC Press, Boca Raton, London and New York, NY

Li, J., Wen, J., \& Jiang, B. (2017). Spatial Spillover Effects of Transport Infrastructure in Chinese New Silk Road Economic Belt.
International Journal of E-Navigation and Maritime Economy, 6, 1-8. http://doi. org/10.1016/j.enavi.2017.05.001

Marquez, M. A., Ramajo, J., \& Hewings, G. J. D. (2010). A spatio-temporal econometric model of regional growth in Spain. Journal of Geographical Systems, 12(2), 207-226. http://doi.org/10.1007/s10109-010-0119-3

Setiawan dan Dwi Endah Kusrini, (2010), Ekonometrika, Andi, Yogyakarta

Statistik, B. P. (2015). Jawa Tengah dalam angka Tahun 2015. BPS, Jawa Tengah.

Statistik, B. P. (2016). Jawa Tengah dalam angka Tahun 2016. BPS, Jawa Tengah.

World Economic Forum. (2016). Competitiveness Global Report 2016-2017. World Economic Forum 